\title{
Introduction to the special issue on form, structure and hylomorphism
}

\author{
Anna Marmodoro ${ }^{1,2} \cdot$ Michele Paolini Paoletti $^{3}(\mathbb{D}$
}

Received: 14 October 2019 / Accepted: 15 October 2019 / Published online: 28 October 2019

(c) Springer Nature B.V. 2019

\section{Abstract}

We summarize in this introduction the contents of all the contributions included in Synthese special issue on form, structure and hylomorphism. Moreover, we provide an exhaustive bibliography of recent research on these topics.

\section{Keywords Form $\cdot$ Structure $\cdot$ Hylomorphism}

Providing a brief and uncontroversial introduction to the metaphysical theory known as hylomorphism (from the Greek hyle matter, and morphé form) is a nearly impossible task, on account of the multiplicity of existing interpretations of Aristotle's original view, and also of the ways his view has been developed, starting with his own immediate commentators. Roughly speaking, hylomorphism is the metaphysical position according to which objects have a "formal" as well as a "material" "component". The philosophical meaning of each of these terms is controversial. In lieu of any inevitably biased account of what these terms refer to, we will here only try to help the reader explore further, with a selected bibliography in appendix.

In this special issue, we have collected papers that develop contemporary versions of hylomorphism, and explore some of its applications. One (even if not the only) dimension along which contemporary hylomorphist accounts differ concerns which types of entity they posit to do the metaphysical work they take an Aristotelian form to do: structures; relations; powers; functions; special sorts of components of complex entities; or sui generis entities - this list is far from being exhaustive. Another dimension concerns the way matter and form are unified and give rise to an hylomorphic compound. A further dimension regards the philosophical consequences of adopting

\footnotetext{
Michele Paolini Paoletti michele.paolinip@gmail.com

Anna Marmodoro anna.marmodoro@durham.ac.uk; anna.marmodoro@philosophy.ox.ac.uk

1 Durham University, Durham, UK

2 University of Oxford, Oxford, UK

3 University of Macerata, Macerata, Italy
} 
hylomorphism as a theory of objects, and which world view follows from that. We have grouped contributions into three broad clusters.

The first includes papers that aim at clarifying the metaphysical commitments of hylomorphism and at defending some specific version of this theory. This is what John Heil does in his "Hylomorphism: what's not like?". According to Heil (but not uncontroversially, given Aristotle's prime mover's counter-example) for Aristotle matter and form cannot exist independently of one another. In Heil's words, "form is what makes it the case that matter makes up an object of a particular kind". However, Heil argues, it is not clear whether according to Aristotle the form of a complex object is some sort of physical activity/process or (in his words) "a principle that that object must satisfy in order to count as the object it is". Moreover, Heil claims, it is not clear from Aristotle's texts whether forms (be they substantial or accidental) are particular or universal. On account of these two issues, Heil finds Aristotle's original version of hylomorphism philosophically underspecified. He thus proceeds to examine two strains of contemporary hylomorphism, stemming from the (alleged) underspecification of Aristotle's original position. The first strain develops the idea that forms are (in Heil's words) "principles: in the case of complex objects, principles of organization - what it is in virtue of which an individual is the kind of thing it is". The second strain takes forms (be as they may powers, processes/activities, or structures) to play a "metaphysical" rather than "formal" role-which he takes to be unifying the components of complex objects into one. On this latter view, forms are, in Heil's words, "top-down' causal factors that emerge in complex systems, features of wholes that oversee the behavior of their parts, features that cannot be accounted for solely by appealing to local interactions among the parts". Yet, Heil argues that this view overlooks the possibility that components could just causally influence themselves, leaving no work to be done by the unifier and thus making the view uneconomical to say the least. This is the reason why Heil favours the first strain; he additionally argues that the first strain of hylomorphism is able to solve puzzles of constitution, which confers extra plausibility to it. Overall, Heil interprets Aristotle as committed to a "blancmange universe", i.e., a universe comprising continuous mixtures of fundamental element; and he argues that such a universe is hard to reconcile with a metaphysics of individual continuants. On the contrary, a blancmange universe should be better thought of as a Spinozian universe with only one substance (i.e., the spacetime continuum) having all prima facie individual continuants as its own modes.

Michele Paolini Paoletti in his "Structures as Relations" develops what seems a plausible although not uncontroversial intuition concerning structures and relations. He first recalls two distinctions: the one between internal and external relations, and that between symmetrical and non-symmetrical relations. Internal relations are those relations that entirely depend on the nature and/or the existence and/or the intrinsic properties of their relata. External relations are those relations that are not internal. A symmetrical relation $R$ between $A$ and $B$ is one that is such that, whenever $A$ stands in $R$ with $\mathrm{B}, \mathrm{B}$ stands in $\mathrm{R}$ with $\mathrm{A}$. A non-symmetrical relation is one that does not meet this condition for being symmetrical. Having introduced these distinctions, Paolini Paoletti argues that structures are external relations between the components of complex entities. He further argues that most structures appear to be non-symmetrical. In external, non-symmetrical relations, the relata must be taken to play different ontological roles 
(O-Roles). Moreover, to avoid Bradley's infamous regress, he takes structures-and relations in general-to be $n+1$-adic modes, i.e., particular $n+1$-adic properties. In the second part of his contribution, Paolini Paoletti argues that complex entities cannot be identified with their structures, nor with their components, nor with their components' standing in the relevant structures. All seemingly complex entities are in fact "simple" - though they entertain specific relations with their "components" structured in specific ways. Some of such relations are explored in the paper: emergence, sustenance, formal influence. This framework, Paolini Paoletti concludes, allows hylomorphists to give satisfactory replies to some objections that have been recently raised against their views.

Jeremy Skrzypek begins his contribution "From Potency to Act: Hyloenergeism" with a discussion of powers hylomorphism, in the versions independently developed by Rea (2011a), Jaworski (2011a, 2014, 2016) and Marmodoro (2013, 2017, 2020). Roughly speaking, and bracketing differences among these views, these authors' idea is that forms qua powers of composites unify the workings of the lower-level powers of components. Furthermore, at least on Jaworski's and Marmodoro's accounts, they also explain the diachronic and synchronic unity of composites. Skrzypek take issue with these views and points out that such unificatory and explanatory task is not performed by the power of a substance but by its manifestation, which he takes to be an entity numerically as well as qualitatively different from the power when dormant. Thus Skrzypek commends a view which he calls hyloenergeism. On his view, forms are activities or processes. All processes are occurrences, though they need to be carefully distinguished from other sorts of occurrences, most notably events. Some processes are homogeneous (i.e., their parts are of the same nature of the whole) and atelic (i.e., they do not culminate in any particular end). Forms are homogeneous and atelic processes. Each form is also a particular and it is kind-specific. When a form qua process begins to involve some relevant matter, a composite material object comes into existence. Matter may change over time, as well as its specific arrangements may. On the contrary, forms qua processes continue to occur and are thus able to ground both the synchronic and the diachronic identity of composite material objects.

The second part of this special issue includes contributions that address wider metaphysical issues from a hylomorphic perspective. Travis Dumsday' contribution focuses on the question "Can a relational substance ontology be hylomorphic?" He introduces the distinction between relational and constitutional ontologies of substance, as follows. On the former, particulars enter into instantiation/exemplification/participation relations with non-spatio-temporal universals. On the latter, particulars are somehow constituted by their universals. Hylomorphism is usually taken to align with the latter view. Yet, according to Dumsday, hylomorphism can also dovetail with a relational substance ontology. After having introduced the substratum theory of substance, he elaborates on a relational ontology substance by distinguishing three different sorts of entities: a transcendent and non-spatio-temporal substance-universal (e.g., electronhood); its manifested instance that is multiply located (e.g., manifested electronhood, that is multiply located where electrons are); and the substratum that "receives" the universal. If however the substratum is inert-as most relational substance ontologists take it to be-then it is unclear how it can give rise to a substance capable of causings and activities. According to Dumsday, we should think of the substratum as "a power 
to give rise to new kinds of substances". Such a power is activated by its external instantiation relation with the transcendent substance-universal (e.g., electronhood). When it is activated, it gives rise to substances belonging to the relevant manifested universal-instance. Dumsday claims that this type of relational ontology of substance is a version of hylomorphism. For the role of prime matter is played by the substratum, whereas the role of substantial form is played by the transcendent universals - though in this case substantial forms are not literally present in the substances, in a somehow non-Aristotelian fashion.

In "Part, Slot, Ground: Foundations for Neo-Aristotelian Mereology" Thomas Sattig assumes (not uncontroversially) that for a neo-Aristotelian a material object is structured by a certain arrangement of slots, ${ }^{1}$ and the object's proper parts are the "fillers" of such slots. Sattig's goal is to take this thought further and reduce, metaphysically, slot-filling to essence and grounding. The reduction of parthood to slot-filling, championed by slot mereologists, and the reduction of slot-filling to essence and grounding, developed by Sattig, when combined yield the reduction of parthood to essence and grounding. If this overarching reduction succeeds, it promises new metaphysical foundations for Neo-Aristotelian mereology, formulated in terms of well-understood notions with powerful applications far beyond the field of mereology. Sattig develops his reductive account of filling a slot in a material object in three steps. In the first step, he gives a rough, initial characterization of the slots to be reduced. This characterization takes the form of seven principles about slots and slot-filling. These principles are chosen to profile slots because they support a number of intuitions about the proper parts of material objects, and hence give some plausibility to the slot-mereologist reduction of parthood to slot-filling. In the second step, Sattig defines several slot-notions in terms of the notions of grounding and essential kind. In the third step, the reduction of the initially characterized slots is completed, by showing that the seven principles about slots and slot-filling are supported by Sattig's definitions together with reasonable assumptions about grounding and essence in the domain of material objects. Finally, Sattig adds clarifications of the proposed reductive account, concerning necessity and causal-functional roles.

The third part of this special issue includes applications of hylomorphism to the philosophy of quantum physics, cosmology and philosophy of mind. Robert C. Koons in his "Thermal substances: a Neo-Aristotelian ontology of the quantum world" aims at locating the category of substance within the framework of contemporary quantum physics. He argues that substances are the only fundamental entities in the universe. They are endowed with independent spatial and temporal unity and able to ground all changes. They cannot be emergent wholes and they cannot have substantial parts, but only virtual, non-substantial ones. For Koons, like for Aristotle and others, living organisms are paradigmatic substances, while most inorganic entities (such as artifacts, groups, the fundamental particles of contemporary physics and the whole universe) cannot qualify as bona fide substances. But his specific stance is that, in addition to organisms, there exist inorganic thermal substances, namely, bodies of matter with thermal, thermodynamic, and chemical properties. Thermal substances

\footnotetext{
${ }^{1}$ Slots may be defined as the different "locations" or "places" (so to say) that the relata of a relation can occupy.
} 
may also become virtual parts of organisms by losing their substantiality. When we move a system with finitely many parts to the continuum limit by treating it as if it contained infinite parts, such parts seemingly function so as to constitute an Aristotelian continuum; they turn out to behave as virtual parts of that continuum. Here a thermal substance seems to arise, with a substantial form that unifies its matter, i.e., its infinite virtual parts. Koons then shows that his hylomorphic interpretation of Primas' model is capable to solve the measurement problems of quantum physics, whereas quantum entanglement is only taken to occur at the level of virtual parts. Finally, five arguments are developed to mark the distinction between thermal substances and their virtual parts.

In his “Quantum Entanglement: A Hylomorphic Account”, Matteo Morganti argues for a hylomorphic interpretation of such a phenomenon in opposition to that provided by Ontic Structural Realism (in short, OSR). On OSR, there are basic relations that are at least as fundamental as objects-or even more fundamental than them. Such relations are able to explain phenomena such as quantum entanglement-unlike objects and their monadic properties. By contrast, hylomorphism—as Morganti sees it - is able to preserve both objects and their monadic properties in quantum entangled systems. He argues that in addition to their particles, quantum entangled systems include an irreducible formal/structural element. This sort of composition characterizing quantum entangled systems gives rise to irreducible correlations between the particles - correlations that did not exist when the particles were not "structured". Morganti takes such correlations to be manifestations of both local dispositions (when they concern the particles) and global ones (when they concern the systems, although global dispositions are nothing more than correlated local dispositions). Morganti then examines the compatibility of his account with different interpretations of quantum physics. Finally, he compares his hylomorphic solution with alternative solutions, such as holism, OSR, and metaphysical coherentism - according to which the components of entangled system mutually depend on one another. Morganti concludes suggesting that metaphysical coherentism "is easily made sense of from the perspective of (powers-based) hylomorphism", because "it can be readily translated into the claim that it is an essential feature of any entangled system $S$ that it is constituted by two or more particles 'structured together' in such a way that their (dispositional) properties are correlated-mutual dependence thus being explained in terms of hylomorphic structure".

John G. Brungardt, in his "World Enough and Form: Why Cosmology Needs Hylomorphism", sketches a hylomorphic theory of cosmology. After providing motivation for adopting a hylomorphist approach to cosmology, Brungardt introduces the notion of cosmic essence. The cosmic essence of something includes both a principle of determination (i.e., a form) and a principle of indetermination (i.e., a matter). A cosmic essence is unified, insofar as it grounds a multiplicity of ordered properties; and in virtue of being unified, it also grounds global emergent properties, i.e., large scale-properties of systems of substances. Brungardt argues that this hylomorphic framework is apt to explain modes of determinate behaviour and their laws, as well as global constants and initial conditions and large-scale processes. Moreover, it is also able to explain the existence of middle-sized objects, of spacetime, the composition of objects and the relations between different scales of the universe. Finally, Brungardt argues that 
hylomorphism can successfully face two further problems: the meta-law dilemma (i.e., how changes of laws in the universe are regulated by further meta-laws) and the problem of explaining the unity and uniqueness of the universe.

In his "Circumnavigating the causal pairing problem with hylomorphism and the integrated information theory of consciousness" Matthew Owen addresses the problem of causal pairing for dualism from a Neo-Thomistic hylomorphic perspective. The problem of causal pairing arises when dualists are required to explain how one specific non-physical mind can be paired with some specific physical effects. For the only relations that can pair causes and effects are spatial relations. Yet, a non-physical mind is non-spatial. Thus, it cannot be successfully paired with its effects-rather than with other effects. On Neo-Thomistic hylomorphim, a human person is a material substance consisting of a substantial form that enforms some portion of matter. A human person's substantial form is her soul, which is non-physical. The en-forming relation is a non-causal, explanatory, grounding relation between the soul and the body, in virtue of which the soul grounds the existence of the body, i.e., it makes the latter the particular type of body it is (and not just a piece of undifferentiated matter). The enforming relation accounts for the pairing between a non-physical mind (now taken as a soul) and its body, though it is not a spatial relation. This, the author argues, delivers the desired solution to the causal pairing problem. Further, the author introduces the integrated information theory of consciousness and its axioms. He shows that, adopting a hylomorphic strategy, the integrated information theory is able to solve the causal pairing problem as well. On such a strategy, consciousness (qua integrated information) is taken to play the role of form with respect to its physical substrate.

In conclusion, we believe that the contributions included in this special issue both prove that contemporary research on hylomorphism is still lively and fruitful and open new prospects for it.

Acknowledgements Funding was provided by Leverhulme Trust (Grant No. D/Ref: 75647).

\section{Appendix: Bibliography on contemporary hylomorphism}

Contemporary versions of hylomorphism have been developed by Fine (1992, 1994a, b, 1999, 2008, 2010, 2017), Oderberg (2002, 2005, 2007), Johnston (2006), Koslicki (2006, 2007, 2008, 2018a, b), Rea (2011a), Jaworski (2011a, b, 2012, 2014, 2016, 2019), Evnine (2013, 2016, 2018), Marmodoro (2013, 2017, 2020), Pruss (2013), Brower (2014), Inman (2014, 2018), Koons (2014, 2017, 2018a), Sattig (2015), Kronen and Menssen (2016), Roudaut (2018), Peramatzis (2018), Tabaczek (2019).

On the relevance of forms for ontological issues such as the constitution of substances and the nature change, see Brower (2010), Toner (2013), Marmodoro and Page (2016), Goswick (2018), Dumsday (2019), Jacinto and Cotnoir (2019).

On the relevance of forms in philosophy of mind, see Cooney (1991), Cohen (1992), Stump (1995, 2003), Barnes (2001), LaRock (2001), Kafetsios and LaRock (2005), Jaworski (2004, 2005, 2006, 2011a, 2016, 2018), Klima (2007), Mouracade (2008), 
Christofidou (2009), Madden (2013a, b), Paolini Paoletti (2016), De Haan (2017, 2018a, b), Horvat (2017), Owen (2019), Reece (2019).

On the relevance of forms in philosophy of physics, see Koons (2018b, c), Pruss (2018).

Concerning philosophy of biology, see Emerton (1984), Shields (2017), Austin and Marmodoro (2018), Austin (2018), Oderberg (2018).

On the relevance of forms in philosophy of religion, see van Dyke $(2009,2012)$, Blaschko (2010), Rea (2011b), Dumsday (2012, 2015), Kronen and Menssen (2012), Jaworski (2013), Madden (2013a), Spencer (2016), Pawl and Spencer (2016), Turner (2018).

On hylomorphism and personal identity, see Oderberg (2002, 2005), Hershenov (2008, 2011), Toner (2011, 2014), Volek (2011), Jaeger (2017), Skrzypek (2017a), Thornton (2019).

Criticisms and critical discussions of hylomorphism have been presented by Williams (1986), Barnes (2003), Britton (2012), Oderberg (2014), Robinson (2014), Sidelle (2014), Bailey (2015), Fairchild (2017), Skrzypek (2017b), Longenecker (2018), Renz (2018), Corradini (2019), Fiocco (2019), Raven (2019).

Further contributions on Neo-Aristotelian themes are included in Tahko (2012) and Novotný and Novák (2014), Simpson et al. (2018).

\section{References}

Austin, C. J. (2018). A biologically informed hylomorphism. In W. M. R. Simpson, R. C. Koons, \& N. J. Teh (Eds.), Neo-Aristotelian perspectives on modern science (pp. 185-210). London: Routledge.

Austin, C. J., \& Marmodoro, A. (2018). Structural powers and the homeodynamic unity of organisms. In W. M. R. Simpson, R. C. Koons, \& N. J. Teh (Eds.), Neo-aristotelian perspectives on modern science (pp. 169-184). London: Routledge.

Bailey, A. M. (2015). The priority principle. Journal of the American Philosophical Association, 1, $163-174$. Barnes, G. P. (2001). Should property-dualists be substance-hylomorphists? Proceedings of the American Catholic Philosophical Association, 75, 285-299.

Barnes, G. P. (2003). The paradoxes of hylomorphism. Review of Metaphysics, 56(3), 501-523.

Blaschko, P. (2010). Resurrection and hylomorphism. moving toward a theory of post-mortem survival compatible with catholic doctrine. Proceedings of the American Catholic Philosophical Association, $84,65-74$.

Britton, T. (2012). The limits of hylomorphism. Metaphysica, 13(2), 145-153.

Brower, J. E. (2010). Aristotelian Endurantism: A new solution to the problem of temporary intrinsics. Mind, 119(476), 883-905.

Brower, J. E. (2014). Aquinas's ontology of the material world: Change, hylomorphism, and material objects. Oxford: Oxford University Press.

Christofidou, A. (2009). Self and self-consciousness: Aristotelian ontology and cartesian duality. Philosophical Investigations, 32(2), 134-162.

Cohen, M. S. (1992). Hylomorphism and functionalism. In M. Nussbaum \& A. Rorty (Eds.), Essays on Aristotle's De Anima (pp. 57-73). Oxford: Clarendon.

Cooney, B. (1991). A hylomorphic theory of mind. Bern: Peter Lang.

Corradini, A. (2019). Hylomorphism: a critical analysis. Acta Analytica, 34(3), 345-361.

De Haan, D. D. (2017). Hylomorphic animalism, emergentism, and the challenge of the new mechanist philosophy of neuroscience. Scientia et Fides, 5(2), 9-38.

De Haan, D. D. (2018a). The interaction of noetic and psychosomatic operations in a thomist hylomorphic anthropology. Scientia et Fides, 6(2), 55-83. 
De Haan, D. D. (2018b). Hylomorphism and the new mechanist philosophy in biology, neuroscience, and psychology. In W. M. R. Simpson, R. C. Koons, \& N. J. Teh (Eds.), Neo-aristotelian perspectives on modern science (pp. 293-325). New York: Routledge.

Dumsday, T. (2012). An argument for hylomorphism or theism. Proceedings of the American Catholic Philosophical Association, 86, 245-254.

Dumsday, T. (2015). A new argument for the incompatibility of hylomorphism and metaphysical naturalism. Proceedings of the American Catholic Philosophical Association, 89, 119-139.

Dumsday, T. (2019). Dispositionalism and the metaphysics of science. Cambridge: Cambridge University Press.

Emerton, N. (1984). The scientific reinterpretation of forms. Ithaca-London: Cornell University Press.

Evnine, S. J. (2013). Ready-mades: Ontology and aesthetics. British Journal of Aesthetics, 53(4), 407-423.

Evnine, S. J. (2016). Making objects and events. A hylomorphic theory of artifacts, actions, and organisms. Oxford: Oxford University Press.

Evnine, S. J. (2018). The use of sets (and other extensional entities) in the analysis of hylomorphically complex objects. Metaphysics, 1(1), 97-109.

Fairchild, M. (2017). A paradox of matter and form. Thought, 6(1), 33-42.

Fine, K. (1992). Aristotle on matter. Mind, 101(401), 35-57.

Fine, K. (1994a). Compounds and aggregates. Noûs, 28(2), 137-158.

Fine, K. (1994b). A puzzle concerning matter and form. In T. Scaltsas, M. L. Gill, \& D. Charles (Eds.), Unity, identity and explanation in Aristotle's metaphysics (pp. 13-40). Oxford: Clarendon.

Fine, K. (1999). Things and their parts. Midwest Studies in Philosophy, 23(1), 61-74.

Fine, K. (2008). Coincidence and form. Aristotelian Society Supplementary, 82(1), 101-118.

Fine, K. (2010). Towards a theory of part. The Journal of Philosophy, 107(11), 559-589.

Fine, K. (2017). Form. The Journal of Philosophy, 114(10), 509-535.

Fiocco, M. O. (2019). Each thing is fundamental: Against hylomorphism and hierarchical structure. American Philosophical Quarterly, 56(3), 289-301.

Goswick, D. (2018). The hard question for hylomorphism. Metaphysics, 1(1), 52-62.

Hershenov, D. B. (2008). A hylomorphic account of thought experiments concerning personal identity. American Catholic Philosophical Quarterly, 82(3), 481-502.

Hershenov, D. B. (2011). Soulless organisms? Hylomorphism vs. animalism. American Catholic Philosophical Quarterly, 85(3), 465-482.

Horvat, S. (2017). Neuroscientific findings in the light of Aquinas' understanding of the human being. Scientia et Fides, 5(2), 127-153.

Inman, R. D. (2014). Neo-Aristotelian plenitude. Philosophical Studies, 168(3), 583-597.

Inman, R. D. (2018). Substance and the fundamentality of the familiar. A neo-Aristotelian mereology. London: Routledge.

Jacinto, B., \& Cotnoir, A. J. (2019). Models for hylomorphism. Journal of Philosophical Logic. https://doi. org/10.1007/s10992-019-09501-3.

Jaeger, A. J. (2017). Hylemorphic animalism and the incarnational problem of identity. Journal of Analytic Theology, 5(1), 145-162.

Jaworski, W. (2004). Hylomorphism and the mind-body problem. Proceedings of the American Catholic Philosophical Association, 78, 178-192.

Jaworski, W. (2005). Hylomorphism and mental causation. Proceedings of the American Catholic Philosophical Association, 79, 201-216.

Jaworski, W. (2006). Hylomorphism and post-cartesian philosophy of mind. Proceedings of the American Catholic Philosophical Association, 80, 209-224.

Jaworski, W. (2011a). Philosophy of mind. A comprehensive introduction. Oxford: Wiley-Blackwell.

Jaworski, W. (2011b). Hylomorphism: What it is and what it isn't. Proceedings of the American Catholic Philosophical Association, 85, 173-187.

Jaworski, W. (2012). Powers, structures, and minds. In R. Groff \& J. Greco (Eds.), Powers and capacities in philosophy: The new aristotelianism (pp. 145-171). London: Routledge.

Jaworski, W. (2013). Hylomorphism and resurrection. European Journal for Philosophy of Religion, 5(1), 197-224.

Jaworski, W. (2014). Hylomorphism and the metaphysics of structure. Res Philosophica, 91, 179-201.

Jaworski, W. (2016). Structure and the metaphysics of mind. Oxford: Oxford University Press.

Jaworski, W. (2018). Hylomorphism and the construct of consciousness. Topoi. https://doi.org/10.1007/ s11245-018-9610-0. 
Jaworski, W. (2019). Hylomorphism and part-whole realism. Ancient Philosophy Today, 1(1), 108-127.

Johnston, M. (2006). Hylomorphism. The Journal of Philosophy, 103(12), 652-698.

Kafetsios, K., \& LaRock, E. (2005). Cognition and emotion: Aristotelian affinities with contemporary emotion research. Theory and Psychology, 15(5), 639-657.

Klima, G. (2007). Thomistic 'Monism' and Cartesian 'Dualism'. Logical Analysis and the History of Philosophy, 10, 92-112.

Koons, R. C. (2014). Staunch vs. faint-hearted hylomorphism: Toward an Aristotelian account of composition. Res Philosophica, 91, 151-177.

Koons, R. C. (2017). The ontological and epistemological superiority of hylomorphism. Synthese. https:// doi.org/10.1007/s11229-016-1295-6.

Koons, R. C. (2018a). Forms as simple and individual grounds of things' natures. Metaphysics, 1(1), 1-11.

Koons, R. C. (2018b). Hylomorphic escalation: An Aristotelian interpretation of quantum thermodynamics and chemistry. American Catholic Philosophical Quarterly, 92(1), 159-178.

Koons, R. C. (2018c). The many world interpretation of quantum mechanics: A hylomorphic critique and alternative”. In W. M. R. Simpson, R. C. Koons, \& N. J. Teh (Eds.), Neo-Aristotelian perspectives on modern science (pp. 61-104). New York: Routledge.

Koslicki, K. (2006). Aristotle's mereology and the status of form. The Journal of Philosophy, 103(12), $715-736$.

Koslicki, K. (2007). Towards a neo-Aristotelian mereology. Dialectica, 61(1), 127-159.

Koslicki, K. (2008). The structure of objects. Oxford: Oxford University Press.

Koslicki, K. (2018a). Form, matter, substance. Oxford: Oxford University Press.

Koslicki, K. (2018b). Towards a hylomorphic solution to the grounding problem. Royal Institute of Philosophy Supplements, 82, 333-364.

Kronen, J., \& Menssen, S. (2012). Hylomorphism and design: A reconsideration of Aquinas's fifth way. The Modern Schoolman, 89(3-4), 155-180.

Kronen, J., \& Menssen, S. (2016). Towards a robust hylomorphism. Studia Neoaristotelica, 13(1), 5-43.

LaRock, E. (2001). Dualistic interaction, neural dependence, and aquinas's composite view. Philosophia Christi, 3(2), 459-472.

Longenecker, M. (2018). Non-concrete parts of material objects. Synthese, 195(11), 5091-5111.

Madden, J. (2013a). Thomistic hylomorphism and philosophy of mind and philosophy of religion. Philosophy Compass, 8(7), 664-676.

Madden, J. (2013b). Mind, matter, and nature: A thomistic proposal for the philosophy of mind. Washington (DC): The Catholic University of America Press.

Marmodoro, A. (2013). Aristotle's hylomorphism, without reconditioning. Philosophical Inquiry, 36, 5-22.

Marmodoro, A. (2017). Power mereology: Structural versus substantial powers. In M. Paolini Paoletti \& F. Orilia (Eds.), Philosophical and scientific perspectives on downward causation (pp. 110-127). London: Routledge.

Marmodoro, A. (2020). Hylomorphic unity. In R. Bliss, \& J. Miller (Eds.), The Routledge handbook of metametaphysics. London: Routledge.

Marmodoro, A., \& Page, B. (2016). Aquinas on forms, substances and artifacts. Vivarium, 54(1), 1-21.

Mouracade, J. (2008). Aristotelian hylomorphism and non-reductive materialism. Apeiron, 41(3), $153-178$.

Novotný, D. D., \& Novák, L. (Eds.). (2014). Neo-Aristotelian perspectives in metaphysics. London: Routledge.

Oderberg, D. S. (2002). Hylomorphism and individuation. In J. Haldane (Ed.), Mind, metaphysics, and value in the thomistic and analytical traditions (pp. 125-142). Notre Dame (IN): University of Notre Dame Press.

Oderberg, D. S. (2005). Hylemorphic dualism. In E. F. Paul, F. D. Miller Jr., \& J. Paul (Eds.), Personal identity (pp. 70-99). Cambridge: Cambridge University Press.

Oderberg, D. S. (2007). Real essentialism. London: Routledge.

Oderberg, D. S. (2014). Is form structure? In D. D. Novotný \& L. Novák(Eds.), Neo-Aristotelian perspectives in metaphysics (pp. 164-180). London-New York: Routledge.

Oderberg, D. S. (2018). The great unifier: Form and the unity of the organism. In W. M. R. Simpson, R. C. Koons, \& N. J. Teh (Eds.), Neo-Aristotelian perspectives on modern science (pp. 210-234). London: Routledge.

Owen, M. (2019). Exploring common ground between integrated information theory and aristotelian metaphysics. Journal of Consciousness Studies, 26(1-2), 163-187. 
Paolini Paoletti, M. (2016). How I (freely) raised my arm: Downward, structural, substance causation. Mind and Matter, 14(2), 203-228.

Pawl, T., \& Spencer, M. K. (2016). Christologically inspired, empirically motivated hylomorphism. Res Philosophica, 93(1), 137-160.

Peramatzis, M. (2018). Aristotle's hylomorphism: The causal-explanatory model. Metaphysics, 1(1), 12-32.

Pruss, A. (2013). Aristotelian forms and laws of nature. Analysis and Existence, 24, 115-132.

Pruss, A. (2018). A traveling forms interpretation of quantum mechanics. In W. M. R. Simpson, R. C. Koons, \& N. J. Teh (Eds.), Neo-Aristotelian perspectives on modern science (pp. 105-122). London: Routledge.

Raven, M. J. (2019). Hylomorphism without forms? A critical notice of Simon Evnine's Making Objects and Events. Canadian Journal of Philosophy, 49(5), 652-669.

Rea, M. C. (2011a). Hylomorphism reconditioned. Philosophical Perspectives, 25, 341-358.

Rea, M. C. (2011b). Hylomorphism and the incarnation. In A. Marmodoro \& J. Hill (Eds.), The metaphysics of the incarnation (pp. 134-152). Oxford: Oxford University Press.

Reece, B. C. (2019). Aristotle's four causes of action. Australasian Journal of Philosophy, 97(2), 213-227.

Renz, G. (2018). Form as structure: It's not so simple. Ratio, 31(1), 20-36.

Robinson, H. (2014). Modern hylomorphism and the reality and causal power of structure: A skeptical investigation. Res Philosophica, 91(2), 203-214.

Roudaut, S. (2018). A dynamic version of hylomorphism. Axiomathes, 28(1), 13-36.

Sattig, T. (2015). The double lives of objects. An essay in the metaphysics of the ordinary world. Oxford: Oxford University Press.

Shields, C. (2017). What organisms once were and might yet be. Philosophy, Theory and Practice in Biology, $9(7), 1-15$.

Sidelle, A. (2014). Does hylomorphism offer a distinctive solution to the grounding problem? Analysis, 74(3), 397-404.

Simpson, W. M. R., Koons, R. C., \& Teh, N. J. (Eds.). (2018). Neo-Aristotelian perspectives on contemporary science. London: Routledge.

Skrzypek, J. (2017a). Hylomorphism and the priority principle. Metaphysica, 18(2), 207-230.

Skrzypek, J. (2017b). Three concerns for structural hylomorphism. Analytic Philosophy, 58(4), 360-408.

Spencer, M. K. (2016). Quantum randomness, hylomorphism, and classical theism. Journal of Analytic Theology, 4(1), 147-170.

Stump, E. (1995). Non-Cartesian substance dualism and materialism without reductionism. Faith and Philosophy, 12, 505-531.

Stump, E. (2003). Aquinas. London-New York: Routledge.

Tabaczek, M. (2019). Emergence. Towards a new metaphysics and philosophy of science. Notre Dame (IN): University of Notre Dame Press.

Tahko, T. E. (Ed.). (2012). Contemporary Aristotelian metaphysics. Cambridge: Cambridge University Press.

Thornton, A. (2019). Disembodied animals. American Philosophical Quarterly, 56(2), 203-217.

Toner, P. (2011). Hylemorphic animalism. Philosophical Studies, 155(1), 65-81.

Toner, P. (2013). On aristotelianism and structures as parts. Ratio, 26(2), 148-161.

Toner, P. (2014). "Hylemorphism, remnant persons and personhood. Canadian Journal of Philosophy, 44(1), 76-96.

Turner, J. T., Jr. (2018). On the resurrection of the dead. A new metaphysics of afterlife for christian thought. London: Routledge.

Van Dyke, C. (2009). Not properly a person: The rational soul and 'thomistic substance dualism'. Faith and Philosophy, 26(2), 186-204.

Van Dyke, C. (2012). The end of life as we know it: Thomas aquinas on persons, bodies and death. The Modern Schoolman, 89(3-4), 243-257.

Volek, P. (2011). Hylomorphism as a solution for freedom and for personal identity. Studia Neoaristotelica, $8(2), 178-188$.

Williams, B. (1986). Hylomorphism. Oxford Studies in Ancient Philosophy, 4, 189-199.

Publisher's Note Springer Nature remains neutral with regard to jurisdictional claims in published maps and institutional affiliations. 